\title{
VARIABEL PENENTU DAN EKSKALASI JUMLAH TABUNGAN MUDHARABAH DI BRI SYARIAH CABANG JEMBER
}

\author{
Ahmad Roziq \\ Universitas Jember \\ abmadroziq@yaboo.com \\ Ika Ratna Qorikaten Rohmah \\ Universitas Jember \\ ikaratna2404@gmail.com
}

\begin{abstract}
The aim of this study was to to examine and analize the confidence level, return of profit sharing, the suitability of sharia law, the reputation of the bank and the acquisition of information influence significantly affect the amount of Mudharabah savings in branch of BRI Syariah Jember. This research is a quantitative research with using type of explanatory research. The results showed that the level of trust significantly influence the amount of Mudharabah savings. Suitability sharia law significantly influence the amount of Mudharabah savings. The bank's reputation significantly influences the amount of Mudharabab savings. Information obtained customers significantly influence on the amount of savings at BRI Syariah Jember with a positive direction.
\end{abstract}

Keywords: Profit Sharing, Saving, Mudharaba

\begin{abstract}
Abstrak
Tujuan dari penelitian ini adalah untuk menguji dan menganalisis pengarub tingkat kepercayaan, bagi hasil, kesesuaian hukum syariah, reputasi bank dan perolehan informasi berpengaruh secara signifikan terhadap jumlah tabungan mudharabah di BRI Syariah Cabang Jember. Penelitian ini adalah penelitian kuantitatif, dengan jenis penelitian explanatory research. Hasil penelitian menunjukan babwa tingkat kepercayaan berpengaruh signifikan terhadap jumlah tabungan mudharabah. Bagi hasil berpengaruh signifikan terhadap jumlah tabungan mudharabah. Kesesuaian bukum syariah berpengarub signifikan terhadap jumlah tabungan mudharabah. Reputasi bank berpengarub signifikan terhadap jumlah tabungan mudharabah. Informasi yang diperoleh nasabah pengarub signifikan terhadap jumlah tabungan mudharabah di BRI Syariah Cabang Jember dengan arah positif.
\end{abstract}

Kata Kunci: Bagi Hasil, Tabungan Mudharabah

Permalink/DOI: http://dx.doi.org/10.18326/infsl3.v10i1.161-186 


\section{Pendahuluan}

BRI Syariah Cabang Jember merupakan salah satu cabang dari BRI Syariah yang terletak di Kabupaten Jember. BRI Syariah Cabang Jember didirikan di Jember semenjak bulan September 2014. Seperti halnya BRI Syariah, BRI Syariah Cabang Jember juga memiliki prestasi yang baik di mata para masyarakat Jember dan sekitarya, hal ini dibuktikan dengan banyaknya jumlah nasabah BRI Syariah Cabang Jember. Pemimpin Cabang BRI Syariah Cabang Jember mengungkapkan bahwasannya "Semenjak didirikan pada 23 September 2013 hingga Januari 2015 BRI Syariah Cabang Jember telah memiliki 4.800 nasabah dengan penambahan ratarata 10 nasabah baru per harinya". Selain itu Pemimpin Cabang BRI Syariah Cabang Jember menuturkan bahwa "Nasabah dari BRI Syariah Cabang Jember tidak hanya berasal dari masyarakat yang ada di sekitar lokasi bank, melainkan hingga daerah Situbondo, Bondowoso, Banyuwangi, dan Lumajang, hal ini dikarenakan banyaknya jenis produk layanan yang ditawarkan kepada nasabah". BRI Syariah Cabang Jember menawarkan berbagai produk layanan, yang salah satunya adalah produk penghimpunan dana kepada para nasabahnya. Produk penghimpunan dana yang ditawarkan oleh BRI Syariah Cabang Jember kepada para nasabahnya merupakan salah satu bentuk sumber dana yang dimilikinya.

Sumber dana bank syariah dibagi menjadi tiga yakni dana pihak pertama, dana pihak kedua, dan dana pihak ketiga Antonio (2011: 76). Dana pihak petama merupakan sumber dana yang berasal dari pemegang saham atau pemilik bank syariah. Dana pihak kedua merupakan dana yang diperoleh dari pihak luar bank baik dalam rupiah maupun valuta asing lazim yang berasal dari pihak yang memberikan pinjaman kepada bank. Dana pihak ketiga merupakan dana yang diperoleh dari masyarakat, dalam arti masyarakat sebagai individu, perusahaan, pemerintah, rumah tangga, koperasi, yayasan, dan lain-lain baik dalam mata uang rupiah maupun dalam valuta asing. Ketiga sumber dana tersebut keberadaannya sangatlah pentig bagi bank syariah. Adanya hal tersebut menimbulkan persaingan antar bank syariah dengan tujuan untuk memperoleh sumber dana yang lebih besar. Pentingnya perolehan dana pihak ketiga yang berasal dari masyarakat membuat bank syariah menawarkan 
berbagai produk penghimpunan dana. Salah satunya adalah produk tabungan mudharabah yang ditawarkan oleh BRI Syariah Cabang Jember

Tabungan mudharabah memiliki sistem pengeolaan dana yang berbeda, dimana bank tidak bertanggung jawab terhadap kerugian yang terjadi bukan akibat kelalaiannya. Namun, bila yang terjadi adalah miss management (salah urus), bank bertanggung jawab penuh atas kerugian tersebut. Dari hasil pengelolaan dana mudharabah, BRI Syariah Cabang Jember akan membagikan hasil kepada pemilik dana syirkah temporer (nasabah) sesuai dengan nisbah yang telah disepakati di awal akad pembukaan rekening.

Tabungan mudharabah merupakan salah satu bentuk produk penghimpunan dana pihak ketiga bank syariah. Dana pihak ketiga yang diperoleh bank syariah dari produk tabungan mudharabah nantinya akan dikelola dengan tujuan perolehan keuntungan yang nantinya akan dibagi dengan nasabah sesuai dengan nisbah yang telah ditentukan di awal. Artinya semakin banyak dana pihak ketiga yang diperoleh bank syariah dalam menghimpun dana dari masyarakat, maka akan semakin besar pula dana yang dapat dikelola untuk memperoleh keuntungan. Adanya hal tersebut tentunya menimbulkan persaingan antar bank syariah untuk memperoleh dana dari pihak ketiga. Persaingan yang dilakukan oleh bank syariah dalam meperoleh dana pihak ketiga mendorong pihak bank syariah untuk saling mengungguli satu sama lain. Persaingan antar bank ini menuntut agar pihak bank syariah mengetahui faktor-faktor yang mempengaruhi jumlah perolehan dana pihak ketiga di bank syariah agar dapat mengguli bank syariah yang lainnya.

Terdapat beberapa penelitian berbeda yang menunjukkan alasan nasabah dalam memilih bank syariah untuk menabung. Menurut Roziq dan Rinanda (2013), "Keputusan memilih tabungan mudharabah dipengaruhi oleh variabel penentu berupa tingkat kepercayaan, pengembalian hasil, kesesuaian hukum syariah dan promosi”. Penelitian lain dilakukan oleh Muchlis pada tahun 2013 menyatakan bahwa, "faktor-faktor yang memengaruhi keputusan nasabah dalam memilih bank adalah faktor kepercayaan atau agama, kejelasan produk bank, failitas dan proses yang diberikan 
perbankan, serta peran dalam keluarga”. Menurut Machmudah tahun 2009 "faktor-faktor yang berpengaruh terhadap minat nasabah non muslim menjadi nasabah di bank secara parsial dan simultan, adalaha lokasi, pelayanan, religius, reputasi, profit sharing dan promosi. Menuury Desiana dan Mohamad Heykal 2011 "faktor yang mempengaruhi pemilihan bank syariah adalah informasi yang diterima oleh nasabah, utamanya adalah informasi bagi hasil, informasi pembiayaan bermasalah, dan informasi pelayanan."

Uraian dari beberapa hasil penelitian tersebut menimbulkan rasa ingin tahu untuk meneliti lima faktor yang kemungkinan dapat mempengaruhi perolehan jumlah dana pihak ketiga di bank syariah. Kelima faktor tersebut adalah tingkat kepercayaan, bagi hasil, kesesuaiian hukum syariah, reputasi dan informasi yang diperoleh nasabah. Lima faktor tersebut dipilih untuk membedakan penelitian ini dengan penelitian sebelumnya.

Penjelasan diatas menggambarkan bahwasannya terdapat pengaruh yang ditimbulkan oleh tingkat kepercayaan, bagi hasil, kesesuaian hukum syariah, reputasi dan informasi yang diperoleh nasabah terhadap jumlah tabungan mudharabah di bank syariah. Berdasarkan pemikiran tersebut, peneliti melakukan penelitian ini dengan tujuan menguji, dan menganalisis pengaruh tingkat kepercayaan, bagi hasil, kesesuaian hukum syariah, reputasi bank dan perolehan informasi berpengaruh secara signifikan terhadap jumlah tabungan mudharabah di BRI Syariah Cabang Jember.

\section{Tinjauan Teoritis}

Kepercayaan

Menurut Dharmmestha (2005: 57) kepercayaan adalah kesediaan seseorang untuk menggantungkan dirinya kepada pihak lain yang terlibat dalam pertukaran karena ia mempunyai keyakinan (confidence) kepada pihak lain tersebut, kepercayaan merupakan harapan umum yang dimiliki individu bahwa kata-kata yang muncul dari pihak lainnya dapat diandalkan. Kepercayaan adalah percaya dan memiliki keyakinan terhadap partner dalam hubungan". Bhattachejee, 2002 dalam Song, 2007 menyatakan bahwa indikator 
dari tingkat kepercayaan adalah kemampuan (ability), benevolence, dan integritas.

\section{Bagi Hasil}

Menurut Antonio (2011: 90) bagi hasil adalah suatu system pengelolaan dana dalam perekonomian islam yakni pembagian hasil usaha antara pemilik modal (shohibul maal) dan pengelola modal (mudharib). Keharaman bunga dalam syariah membawa konsekuensi adanya penghapusan bunga secara mutlak. Menurut Mustaqim, 2006 indikator dari bagi hasil meliputi nisbah bagi hasil, bagi hasil sesuai dengan akad, keuntungan yang diperoleh atas pengelolaan dana, serta saldo nominal tabungan nasabah.

\section{Kesesuaian Hukum Syariah}

Menurut Wirdyaningsih (2005 :39) "Prinsip utama yang dianut bank syariah adalah: larangan riba (bunga) dalam berbagai bentuk transaksi, menjalankan bisnis dan aktivitas perdagangan yang berbasis pada memperoleh keuntungan yang sah menurut syariah, dan menumbuh kembangkan zakat." Internalisasi nilai-nilai ajaran agama yang diyakini tidak mustahil dan tidak bertentangan dengan logika yang kemudian diekspresikan dalam kehidupan sosial kemasyarakatan. Menurut Rahmawaty (2008) indikator dari kesesuaiaan hukum syariah adalah Rahmawaty (2008) menyatakan bahwa "pelaksanaan segala transaksi pada lembaga keuangan syariah akan mencapai kesesuaian hukum syariah, apabila dalam pelaksanaan setiap transaksi terhindar dari unsur-unsur maysir, gharar, haram, riba, dan bathil.

\section{Reputasi Bank}

Menurut Fitrijanti (2005:33) menyatakan bahwa reputasi adalah bonatifitas nama suatu perusahaan menurut pandangan lembaga atau kelompok tertentu yang berkepentingan dengan perusahaan tersebut". Reputasi bank diartikan sebagai suatu bangunan sosial yang mengayomi suatu hubungan, kepercayaan yang akhirnya 
akan menciptakan brand image bagi suatu perusahaan. Reputasi yang baik dan terpercaya merupakan sumber keunggulan bersaing suatu bank. Adanya reputasi yang baik dalam sebuah perusahaan bank akan menimbulkan kepercayaan bagi nasabahnya. Suatu kepercayaan adalah pikiran deskriptif oleh seorang mengenai suatu pandangan paling dominan yang menunjukkan bahwa sikap terhadap merek yaitu reputasi atau penyedia jasa lebih merupakan evaluasi keseluruhan jangka panjang dibanding elemen kepuasan. Menurut Putranti (2005), indikator dari reputasi adalah faktor manajemen perusahaan, prospek usaha, produk, ketersediaan produk, lingkungan kerja, tanggung jawab sosial, ketertarikan emosional, identitas perusahaan dan kinerja keuangan.

\section{Informasi yang Diperoleh Nasabah}

Menurut Kusrini dan Koniyo (2007:7) Informasi adalah data yang sudah diolah menjadi sebuah bentuk yang berarti bagi pengguna, yang bermanfaat dalam pengambilan keputusan saat ini atau mendukung sumber informasi. Menurut Lupiyoadi, 2006 indikator dari informasi yang diperoleh nasabah adalah informasi mengenai saldo awal penyetoran, tingkat persentase bagi hasil, ketentuan yang harus dilakukan oleh nasabah, kelebihan maupun kekurangan yang terdapat pada produk, dan hasil keuntungan yang diperoleh.

\section{Tabungan Mudharabah}

Tabungan mudharabah merupakan simpanan nasabah di bank syariah yang menggunakan prinsip mudharabah. Antonio (2011:155) menyatakan, "Tabungan mudharabah adalah tabungan yang menerapkan akad mudharabah,diantaranya adalah keuntungan dari dana yang digunakan harus dibagi antara nasabah (shahibul maal) dan bank (mudharib) dan adanya tenggang.

\section{Penelitian Terdahulu}

Muhlis (2011) melakukan penelitian Nasabah BRI Syariah, bank Syariah Mandiri, dan Bank Mega Syariah yang ada di kota 
Semarang, Pekalongn, purwokerto, dan Solo. Penelitiannya menyimpulkan bahwa Religiusitas berpengaruh positif terhadap perilaku menabung. Kelompok masyarakat muslim cenderung meningkatkan tabungannya dan menetapkan dirinya cenderung sebagai nasabah karena alasan emosional-ideologis Hasil Kedua dari penelitian tersebut adalah tingkat bagi hasil berpengaruh positif dan signifikan terhadap perilaku menabung di bank syariah bagi semua kelompok nasabah. Dan hasil ketiga tingkat kepercayaan atas soliditas dan reputasi bank syariah berpengaruh positif, dan signifikan bagi peningkatan tabungan nasabah.

\section{Kerangka Konseptual Penelitian}

Hubungan antar variabel dalam penelitian ini dapat dijelaskan dalam gambar kerangaka konseptual di bawah ini.

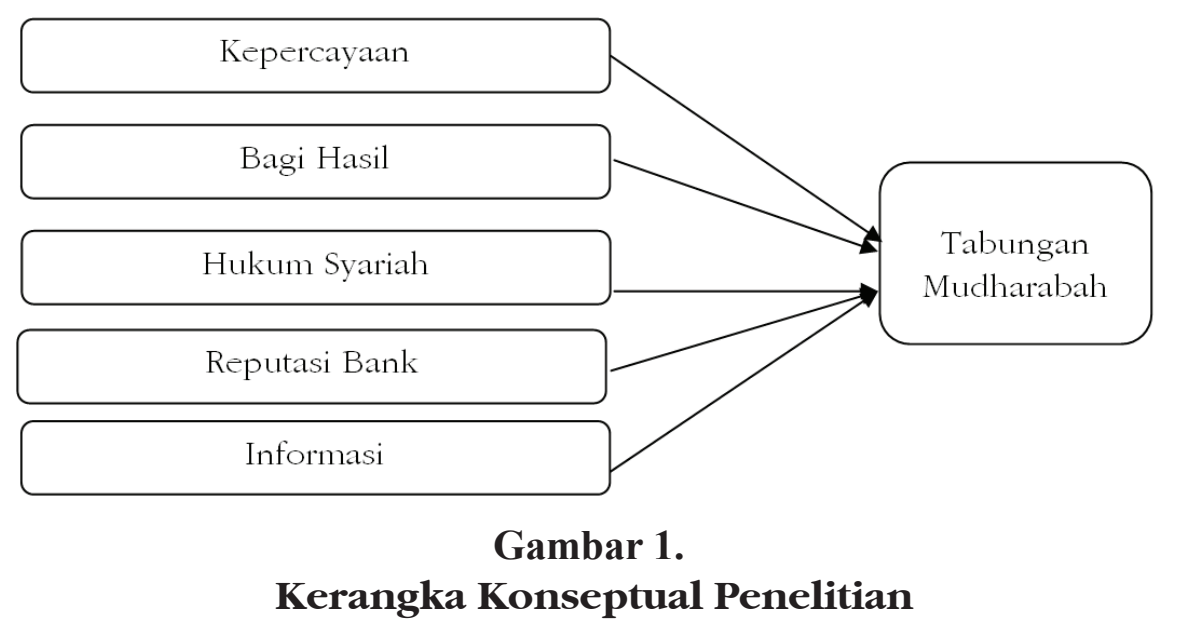

Hipotesis yang akan diuji dalam peneltian ini adalah sebagai berikut:

H1 : Tingkat kepercayaan berpengaruh signifikan terhadap jumlah tabungan mudharabah di BRI Syariah Cabang Jember

H2 : Bagi hasil berpengaruh signifikan terhadap jumlah tabungan mudharabah di BRI Syariah Cabang Jember

H3 : Kesesuaian hukum syariah berpengaruh berpengaruh signifikan terhadap jumlah tabungan mudharabah di BRI Syariah Cabang Jember 
H4 : Reputasi bank berpengaruh berpengaruh signifikan terhadap jumlah tabungan mudharabah di BRI Syariah Cabang Jember

H5 : Informasi yang diperoleh nasabah berpengaruh berpengaruh signifikan terhadap jumlah tabungan mudharabah di BRI Syariah Cabang Jember

\section{Metode Penelitian}

Penelitian ini adalah penelitian kuantitatif, yaitu penelitian yang datanya diperoleh dan dianalisis dalam bentuk angka, mulai dari pengumpulan data, penafsiran terhadap data tersebut dan penampilan hasilnya. Jenis penelitian ini adalah explanatory research, yang menjelaskan hubungan kausal/pengaruh varibelvariabel melalui pengujian hipotesis. Penelitian ini menguji dan menjelaskan pengaruh tingkat kepercayaan, bagi hasil, kesesuaian hukum syariah, reputasi bank, dan informasi yang diperoleh nasabah terhadap jumlah tabungan mudharabah di BRI Syariah Cabang Jember.

Kepercayaan adalah percaya dan memiliki keyakinan terhadap partner dalam hubungan. Bagi hasil adalah pembagian hasil usaha antara pemilik modal (shobibul maal) dan pengelola modal ( mudharib). Reputasi bank diartikan sebagai suatu bangunan sosial yang mengayomi suatu hubungan, kepercayaan yang akhirnya akan menciptakan brand image bagi suatu perusahaan. kesesuaiaan hukum syariah adalah pelaksanaan segala transaksi pada lembaga keuangan syariah akan mencapai kesesuaian hukum syariah, apabila dalam pelaksanaan setiap transaksi terhindar dari unsur-unsur maysir, gharar, haram, riba, dan bathil. Informasi adalah data yang sudah diolah menjadi sebuah bentuk yang berarti bagi pengguna, yang bermanfaat dalam pengambilan keputusan saat ini atau mendukung sumber informasi. Tabungan mudharabah merupakan simpanan nasabah di bank syariah yang menggunakan prinsip mudharabah.

Tehnik analisis yang digunakan yaitu meliputi analisis deskriptif dan analisis multiple regression melalui uji statistik yang terdidi dari; uji validitas, uji reliabilitas, uji normalitas, uji 
multikolinieritas, dan uji linieritas, uji $\mathrm{F}$ dan Uji $\mathrm{t}$ dan uji koefisien determinasi.

\section{Analisis Dan Pembahasan}

Analisis Statistik Deskriptif

Analisis deskriptif statistik ini dapat digunakan untuk memberikan penjelasan dalam penelitian lanjutan guna memberikan hasil penelitian yang lebih baik terhadap analisis regresi. Analisis deskriptif statistik bersifat penjelasan statistik dengan memberikan gambaran data tentang jumlah data, nilai minimum, nilai maxsimum, mean, dan standar deviasi datanya. Adapun hasil uji analisis deskriptif statistik adalah sebagai berikut.

Tabel 1.

Hasil Analisis Deskriptif Statistik

\begin{tabular}{|c|c|c|c|c|c|}
\hline Keterangan & $\mathrm{N}$ & Minimum & Maximum & Mean & $\begin{array}{c}\text { Std. } \\
\text { Deviation }\end{array}$ \\
\hline Tingkat kepercayaan $\left(\mathrm{X}_{1}\right)$ & 60 & 3,5 & 4,6 & 4,07 & 0,24 \\
\hline Bagi hasil $\left(\mathrm{X}_{2}\right)$ & 60 & 3,5 & 4,75 & 4,12 & 0,25 \\
\hline $\begin{array}{l}\text { Kesesuaian hukum } \\
\text { syariah }\left(\mathrm{X}_{3}\right)\end{array}$ & 60 & 3,5 & 4,67 & 4,11 & 0,25 \\
\hline Reputasi bank $\left(\mathrm{X}_{4}\right)$ & 60 & 3,56 & 4,67 & 4,11 & 0,26 \\
\hline $\begin{array}{l}\text { Informasi yang diperoleh } \\
\text { nasabah }\left(\mathrm{X}_{5}\right)\end{array}$ & 60 & 3,4 & 4,6 & 4,03 & 0,32 \\
\hline $\begin{array}{l}\text { Jumlah tabungan } \\
\text { mudharabah (Y) } \\
\text { Valid } \mathrm{N} \text { (listwise) }\end{array}$ & $\begin{array}{l}60 \\
60\end{array}$ & 3,5 & 4,67 & 4,11 & 0,27 \\
\hline
\end{tabular}

Berdasarkan tabel 1. diatas, berkaitan dengan analisis deskriptif statistik maka dapat dilihat bahwa dengan jumlah data sebanyak 60 yang berasal dari 60 responden, variabel jumlah tabungan mudharabab (Y) mempunyai rata-rata sebesar 4,11, dengan nilai minimal 3,5 dan nilai maksimal 4,67, sedangkan standar devisiasinya sebesar 0,27\%. Variabel tingkat kepercayaan ( $\mathrm{X}_{1}$ ) mempunyai rata-rata 4,07, dengan nilai minimal 3,5 dan nilai maksimal 4,6, sedangkan standar devisiasinya sebesar 0,24\%. Variabel bagi hasil 
$\left(\mathrm{X}_{2}\right)$ mempunyai rata-rata sebesar 4,12, dengan nilai minimal 3,5 dan nilai maksimal 4,75, sedangkan standar devisiasinya sebesar $0,25 \%$. Variabel kesesuaian hukum syariah $\left(\mathrm{X}_{3}\right)$ mempunyai ratarata sebesar 4,11, dengan nilai minimal 3,5 dan nilai maksimal 4,67, sedangkan standar devisiasinya sebesar 0,25\%. Variabel reputasi bank $\left(\mathrm{X}_{4}\right)$ mempunyai rata-rata sebesar 4,11 , dengan nilai minimal 3,56 dan nilai maksimal 4,67, sedangkan standar devisiasinya sebesar $0,26 \%$. Variabel informasi yang diperoleh nasabah $\left(\mathrm{X}_{5}\right)$ mempunyai rata-rata sebesar 4,03, dengan nilai minimal 3,4 dan maksimal 4,6, sedangkan standar devisiasinya sebesar $0,32 \%$

\section{Uji Validitas dan Uji Reliabilitas}

Uji validitas dimaksudkan untuk mengetahui seberapa besar ketepatan dan kecermatan suatu alat ukur dalam melakukan fungsi ukurnya. Tabel 2 berikut menjelaskan hasil pengujian validitas. ;

\section{Tabel 2.}

\section{Hasil Uji Validitas}

\begin{tabular}{ccccc}
\hline Indikator & $\begin{array}{c}\text { Product Moment } \\
\text { Pearson's }\end{array}$ & Sig. & $a$ & Keterangan \\
\hline $\mathrm{X}_{1.1}$ & 0,364 & $0,004<0,05$ & Valid \\
$\mathrm{X}_{1.2}$ & 0,468 & $0,000<0,05$ & Valid \\
$\mathrm{X}_{1.3}$ & 0,538 & $0,000<0,05$ & Valid \\
$\mathrm{X}_{1.4}$ & 0,476 & $0,000<0,05$ & Valid \\
$\mathrm{X}_{1.5}$ & 0,344 & $0,007<0,05$ & Valid \\
$\mathrm{X}_{1.6}$ & 0,441 & $0,000<0,05$ & Valid \\
$\mathrm{X}_{1.7}$ & 0,370 & $0,004<0,05$ & Valid \\
$\mathrm{X}_{1.8}$ & 0,452 & $0,000<0,05$ & Valid \\
$\mathrm{X}_{1.9}$ & 0,451 & $0,000<0,05$ & Valid \\
$\mathrm{X}_{1.10}$ & 0,449 & $0,000<0,05$ & Valid
\end{tabular}




\begin{tabular}{llll}
$\mathrm{X}_{2.1}$ & 0,536 & $0,000<0,05$ & Valid \\
$\mathrm{X}_{2.2}$ & 0,550 & $0,000<0,05$ & Valid \\
$\mathrm{X}_{2.3}$ & 0,455 & $0,000<0,05$ & Valid \\
$\mathrm{X}_{2.4}$ & 0,476 & $0,000<0,05$ & Valid \\
$\mathrm{X}_{3.1}$ & 0,504 & $0,000<0,05$ & Valid \\
$\mathrm{X}_{3.2}$ & 0,507 & $0,000<0,05$ & Valid \\
$\mathrm{X}_{3.3}$ & 0,414 & $0,001<0,05$ & Valid \\
$\mathrm{X}_{3.4}$ & 0,503 & $0,000<0,05$ & Valid \\
\hline
\end{tabular}

\section{Lanjutan Tabel 2.}

Uji Validitas

\begin{tabular}{|c|c|c|c|c|c|}
\hline Indikator & $\begin{array}{l}\text { Product Moment } \\
\text { Pearson's }\end{array}$ & Sig. & & $a$ & Keterangan \\
\hline $\mathrm{X}_{3.5}$ & 0,444 & 0,000 & $<$ & 0,05 & Valid \\
\hline $\mathrm{X}_{3.6}$ & 0,623 & 0,000 & $<$ & 0,05 & Valid \\
\hline $\mathrm{X}_{4.1}$ & 0,396 & 0,004 & $<$ & 0,05 & Valid \\
\hline $\mathrm{X}_{4.2}$ & 0,544 & 0,000 & $<$ & 0,05 & Valid \\
\hline $\mathrm{X}_{4.3}$ & 0,333 & 0,009 & $<$ & 0,05 & Valid \\
\hline $\mathrm{X}_{4.4}$ & 0,515 & 0,000 & $<$ & 0,05 & Valid \\
\hline $\mathrm{X}_{4.5}$ & 0,395 & 0,002 & $<$ & 0,05 & Valid \\
\hline $\mathrm{X}_{4.6}$ & 0,629 & 0,000 & $<$ & 0,05 & Valid \\
\hline $\mathrm{X}_{4.7}$ & 0,443 & 0,000 & $<$ & 0,05 & Valid \\
\hline $\mathrm{X}_{4.8}$ & 0,424 & 0,001 & $<$ & 0,05 & Valid \\
\hline $\mathrm{X}_{4.9}$ & 0,647 & 0,000 & $<$ & 0,05 & Valid \\
\hline
\end{tabular}




\begin{tabular}{ccccc}
$\mathrm{X}_{5.1}$ & 0,663 & $0,000<0,05$ & Valid \\
$\mathrm{X}_{5.2}$ & 0,501 & $0,000<0,05$ & Valid \\
$\mathrm{X}_{5.3}$ & 0,553 & $0,000<0,05$ & Valid \\
$\mathrm{X}_{5.4}$ & 0,670 & $0,000<0,05$ & Valid \\
$\mathrm{X}_{5.5}$ & 0,620 & $0,000<0,05$ & Valid \\
$\mathrm{Y}_{1}$ & 0,583 & $0,000<0,05$ & Valid \\
$\mathrm{Y}_{2}$ & 0,513 & $0,000<0,05$ & Valid \\
$\mathrm{Y}_{3}$ & 0,479 & $0,000<0,05$ & Valid \\
$\mathrm{Y}_{4}$ & 0,444 & $0,000<0,05$ & Valid \\
$\mathrm{Y}_{5}$ & 0,442 & $0,000<0,05$ & Valid \\
$\mathrm{Y}_{6}$ & 0,626 & $0,000<0,05$ & Valid \\
\hline
\end{tabular}

Berdasarkan tabel 2 diketahui bahwa masing-masing indikator (item) dalam variabel yang digunakan mempunyai hasil nilai product moment pearson's dengan signifikasi 0,000 - 0,009 < 0,05, sehingga indikator (item) yang digunakan dalam variabel penelitian ini dapat dinyatakan sesuai atau relevan dan dapat digunakan sebagai item dalam pengumpulan data.

Uji reliabilitas menggunakan cronbach's alpha. Suatu instrument dikatakan reliabel apabila cronbach's alpha lebih besar dari 0,60 (Prayitno, 2010:97). Berikut pada tabel 3 disajikan hasil pengujian reliabilitas ;

Tabel 3.

Hasil Uji Reliabilitas

\begin{tabular}{ccccc}
\hline Variabel & Cronbachs Alpha & Cutt off & Nof Item & Keterangan \\
\hline $\mathrm{X}_{1}$ & 0,724 & $>0,6$ & 10 & Reliabel \\
$\mathrm{X}_{2}$ & 0,735 & $>0,6$ & 4 & Reliabel
\end{tabular}




\begin{tabular}{ccccc}
\hline Variabel & Cronbachs Alpha & Cutt off & Nof Item & Keterangan \\
\hline $\mathrm{X}_{3}$ & 0,640 & $>0,6$ & 6 & Reliabel \\
$\mathrm{X}_{4}$ & 0,679 & $>0,6$ & 9 & Reliabel \\
$\mathrm{X}_{5}$ & 0,659 & $>0,6$ & 5 & Reliabel \\
$\mathrm{Y}$ & 0,649 & $>0,6$ & 6 & Reliabel \\
\hline
\end{tabular}

Berdasarkan Tabel 3, hasil uji reliabilitas diatas menunjukkan bahwa data yang diperoleh bersifat reliabel karena nilai Cronbach's Alpha yakni 0,724, 0,735, 0,640, 0,679, 0,659 dan 0,649>0,60, sehingga data yang diperoleh dapat dinyatakan reliabel atau layak sebagai alat dalam pengumpulan data.

\section{Uji Asumsi Klasik}

Uji normalitas yang dilakukan terhadap sampel dilakukan dengan mengunakan kolmogorov-smirnov test dengan menetapkan derajat keyakinan $(\alpha)$ sebesar 5\%. Adapun hasil pengujian dapat disajikan pada tabel 4 berikut;

\section{Tabel 4}

\section{Hasil Uji Normalitas}

\begin{tabular}{|c|c|c|c|c|}
\hline \multirow{2}{*}{ Test of Normality } & \multicolumn{4}{|c|}{ Kolmogorov-Smirnov } \\
\hline & Sig. & & Cutt off & Keterangan \\
\hline Tingkat kepercayaan $\left(\mathrm{X}_{1}\right)$ & 0,137 & $>$ & 0,05 & Normal \\
\hline Bagi hasil $\left(\mathrm{X}_{2}\right)$ & 0,105 & $>$ & 0,05 & Normal \\
\hline Kesesuaian hukum syariah $\left(\mathrm{X}_{3}\right)$ & 0,112 & $>$ & 0,05 & Normal \\
\hline Reputasi bank $\left(\mathrm{X}_{4}\right)$ & 0,124 & $>$ & 0,05 & Normal \\
\hline $\begin{array}{l}\text { Informasi yang diperoleh nasabah } \\
\left(\mathrm{X}_{5}\right)\end{array}$ & 0,088 & $>$ & 0,05 & Normal \\
\hline Jumlah tabungan mudharabah (Y) & 0,145 & $>$ & 0,05 & Normal \\
\hline
\end{tabular}


Berdasarkan tabel 4 dapat diketahui bahwa nilai probabilitas atau signifikansi untuk masing-masing variabel lebih besar dari 0,05 , sehingga dapat dinyatakan bahwa data dalam penelitian ini berdistribusi normal.

Uji multikolineritas digunakan untuk mengetahui ada atau tidaknya hubungan linear dalam variabel independen dalam model. Ada atau tidaknya multikolinearitas dapat dilihat dari nilai Variance Inflation Factor (VIF). Adapun hasil pengujian dapat disajikan pada tabel 5 berikut;

Tabel 5.

Uji Multikolinearitas

\begin{tabular}{|c|c|c|c|c|}
\hline Test of Multikolinierity & VIF & & Cutt off & Keterangan \\
\hline Tingkat kepercayaan $\left(\mathrm{X}_{1}\right)$ & 1,801 & $<$ & 10 & $\begin{array}{l}\text { Tidak terjadi } \\
\text { mulitikolinieritas }\end{array}$ \\
\hline Bagi hasil $\left(\mathrm{X}_{2}\right)$ & 1,862 & $<$ & 10 & $\begin{array}{l}\text { Tidak terjadi } \\
\text { mulitikolinieritas }\end{array}$ \\
\hline Kesesuaian hukum syariah $\left(\mathrm{X}_{3}\right)$ & 1,593 & $<$ & 10 & $\begin{array}{l}\text { Tidak terjadi } \\
\text { mulitikolinieritas }\end{array}$ \\
\hline Reputasi bank $\left(\mathrm{X}_{4}\right)$ & 1,449 & $<$ & 10 & $\begin{array}{l}\text { Tidak terjadi } \\
\text { mulitikolinieritas }\end{array}$ \\
\hline $\begin{array}{l}\text { Informasi yang diperoleh } \\
\text { nasabah }\left(\mathrm{X}_{5}\right)\end{array}$ & 1,708 & $<$ & 10 & $\begin{array}{l}\text { Tidak terjadi } \\
\text { mulitikolinieritas }\end{array}$ \\
\hline
\end{tabular}

Sumber: Lampiran 5

Tabel 5 menunjukkan bahwa tidak terjadi multikolinearitas antar variabel independen karena menunjukkan nilai VIF kurang dari 10.

Uji heteroskedastisitas bertujuan untuk menguji apakah dalam sebuah model regresi terjadi ketidaksamaan varian dari residual dari satu pengamatan ke pengamatan yang lain. Cara memprediksi ada tidaknya heteroskedastisitas pada suatu model dapat dilihat dari pola gambar scatterplot model tersebut seperti pada gambar 2 berikut ini. 
Scatterplot

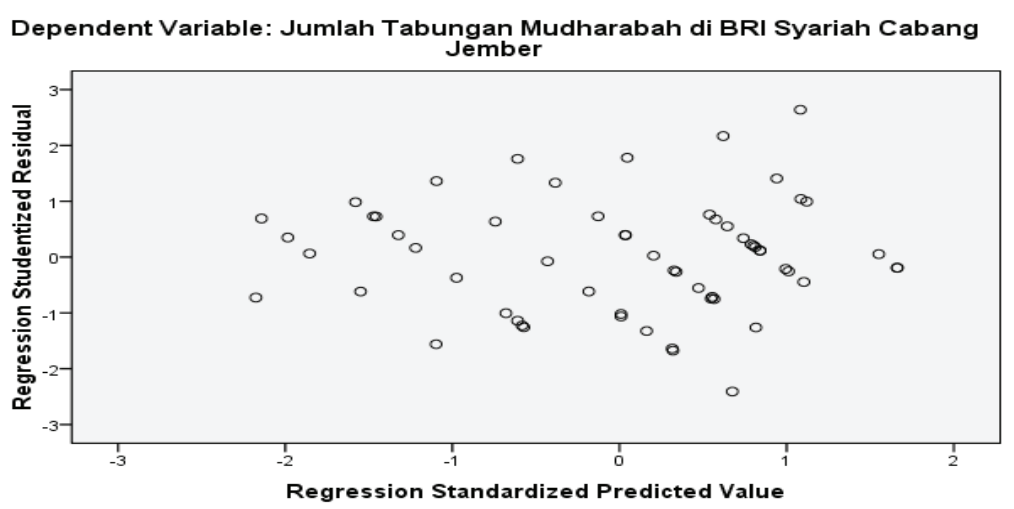

Gambar 2

Hasil Uji Heteroskedastisitas

Gambar 2, menunjukkan bahwa tidak adanya heteroskedastisitas, karena tebaran data tidak membentuk garis tertentu atau tidak terdapat pola yang jelas, serta titik-titik menyebar diatas dan dibawah angka nol pada sumbu Y.

\section{Uji Hipotesis}

Uji $\mathrm{F}$ dimaksudkan untuk mengetahui pengaruh tingkat kepercayaan, bagi hasil, kesesuaian hukum syariah, reputasi bank dan informasi yang diperoleh nasabah terhadap variabel dependen yaitu jumlah tabungan mudharabah secara simultan. Tabel distribusi F dicari pada $\alpha=5 \%$, dengan derajat kebebasan (df) df1 atau 6-1 = 5 , dan df 2 n-k-1 atau 60-5-1 = 54. Berdasarkan hasil analisis regresi linear berganda (dalam hal ini untuk menguji pengaruh secara simultan) diperoleh hasil, yaitu bahwa $\mathrm{F}_{\text {hitung }}>\mathrm{F}_{\text {tabel }}(50,232>2,39)$ dan signifikasi $(0,000<0,05)$, maka Ho ditolak dan Ha diterima, artinya variabel tingkat kepercayaan, bagi hasil, kesesuaian hukum syariah, reputasi bank dan informasi yang diperoleh nasabah secara simultan berpengaruh signifikan terhadap jumlah tabungan mudharabah di BRI Syariah Cabang Jember. 
Uji t dilakukan untuk mengetahui apakah variabel independen berpengaruh terhadap variabel dependen secara signifikan secara parsial. Tabel distribusi t dicari pada $\alpha=5 \%$ (uji 2 sisi, $5 \%: 2=2,5 \%$ atau $0,025)$, dengan derajat kebebasan (df) $n-k-1$ atau $60-5-1=54$. Hasil analisis regresi berganda adalah untuk mengetahui pengaruh tingkat kepercayaan, bagi hasil, kesesuaian hukum syariah, reputasi bank dan informasi yang diperoleh nasabah terhadap variabel dependen yaitu jumlah tabungan.Analisis regresi berganda berkaitan dengan studi ketergantungan suatu variabel dependen pada satu atau lebih variabel independen dengan tujuan untuk mengetahui seberapa besar pengaruh variabel independen terhadap variabel dependen. Pada intinya Analisis Regresi Linear Berganda digunakan untuk mengukur pengaruh antara lebih dari satu variabel prediktor (variabel bebas) terhadap variabel terikatAnalisis ini digunakan untuk mengetahui apakah masing-masing variabel independen berhubungan positif atau negatif dan untuk memprediksi nilai dari variabel dependen mengalami kenaikan atau penurunan. Hasil analisis regresi linear berganda antara variabel independen yaitu tingkat kepercayaan, bagi hasil, kesesuaian hukum syariah, reputasi bank dan informasi yang diperoleh nasabah, serta variabel dependen yaitu jumlah tabungan. Berikut pada Tabel 6 disajikan hasil analisis regresi linear berganda :

Tabel 6.

Hasil Regresi Linear Berganda

\begin{tabular}{|c|c|c|c|c|c|c|c|c|}
\hline $\begin{array}{l}\text { Variabel } \\
\text { Independent }\end{array}$ & $\begin{array}{c}\text { Unstandardiz } \\
\text { ed } \\
\text { Coefficients B }\end{array}$ & $\mathrm{t}$ & & $t_{\text {tabel }}$ & Sig. & & $a$ & Keterangan \\
\hline (Constant) & $-0,787$ & & - & & & - & & - \\
\hline $\begin{array}{l}\text { Tingkat } \\
\text { kepercayaan }\left(\mathrm{X}_{1}\right)\end{array}$ & 0,284 & 3,336 & $>$ & 2,004 & 0,002 & $<$ & 0,05 & Signifikan \\
\hline Bagi hasil $\left(\mathrm{X}_{2}\right)$ & 0,245 & 2,998 & $>$ & 2,004 & 0,004 & $<$ & 0,05 & Signifikan \\
\hline $\begin{array}{l}\text { Kesesuaian } \\
\text { hukum syariah } \\
\left(\mathrm{X}_{3}\right)\end{array}$ & 0,225 & 2,972 & $>$ & 2,004 & 0,004 & $<$ & 0,05 & Signifikan \\
\hline $\begin{array}{l}\text { Reputasi bank } \\
\left(\mathrm{X}_{4}\right)\end{array}$ & 0,265 & 3,694 & $>$ & 2,004 & 0,001 & $<$ & 0,05 & Signifikan \\
\hline $\begin{array}{l}\text { Informasi yang } \\
\text { diperoleh nasabah } \\
\left(\mathrm{X}_{5}\right)\end{array}$ & 0,178 & 2,826 & $>$ & 2,004 & 0,007 & $<$ & 0,05 & Signifikan \\
\hline \multicolumn{2}{|c|}{ Adjusted $R$ Square $=0,807$} & Sig. $F$ & & & & & \multicolumn{2}{|c|}{ F. Hitung $=50,232$} \\
\hline
\end{tabular}


Berdasarkan koefisien regresi, maka persamaan regresi yang dapat dibentuk adalah.

$$
Y=-0,787+0,284 X_{1}+0,245 X_{2}+0,225 X_{3}+0,265 X_{4}+0,178 X_{5}
$$

1. Nilai konstanta $-0,787$, menunjukkan bahwa jika tidak ada aktivitas pada tingkat kepercayaan, bagi hasil, kesesuaian hukum syariah, reputasi bank dan informasi yang diperoleh nasabah maka nilai jumlah tabungan mudharabah sebesar $-0,787$;

2. Nilai koefisien 0,284 pada tingkat kepercayaan, menunjukkan bahwa setiap adanya kenaikan kegiatan tingkat kepercayaan 1 satuan, maka hal tersebut akan meningkatkan jumlah tabungan mudharabah sebesar 0,284, dan sebaliknya;

3. Nilai koefisien 0,245 pada bagi hasil, menunjukkan bahwa setiap adanya kenaikan kegiatan bagi hasil 1 satuan, maka hal tersebut akan meningkatkan jumlah tabungan mudharabah sebesar 0,245, dan sebaliknya;

4. Nilai koefisien 0,225 pada kesesuaian hukum syariah, menunjukkan bahwa setiap adanya kenaikan kegiatan kesesuaian hukum syariah 1 satuan, maka hal tersebut akan meningkatkan jumlah tabungan mudharabah sebesar 0,225, dan sebaliknya;

5. Nilai koefisien 0,265 pada reputasi bank, menunjukkan bahwa setiap adanya kenaikan kegiatan reputasi bank 1 satuan, maka hal tersebut akan meningkatkan jumlah tabungan mudharabah sebesar 0,265, dan sebaliknya;

6. Nilai koefisien 0,178 pada informasi yang diperoleh nasabah, menunjukkan bahwa setiap adanya kenaikan kegiatan informasi yang diperoleh nasabah 1 satuan, maka hal tersebut akan meningkatkan jumlah tabungan mudharabab sebesar 0,178, dan sebaliknya.

Berdasarkan hasil analisis regresi linear berganda (dalam hal ini untuk menguji pengaruh secara parsial) diperoleh hasil yang dapat dinyatakan berikut ; 
1. Variabel tingkat kepercayaan $\left(\mathrm{X}_{1}\right)$ memiliki nilai t 3,336 > 2,004 dan signifikasi 0,002 <0,05, maka Ho ditolak dan Ha diterima, yang berarti secara parsial variabel tingkat kepercayaan berpengaruh signifikan terhadap jumlah tabungan mudharabah di BRI Syariah Cabang Jember. Selain itu $t_{\text {hitung }}$ yang diperoleh adalah positif, oleh karena itu, apabila ada peningkatan pada variabel tingkat kepercayaan maka akan meningkatkan jumlah tabungan mudharabab;

2. Variabel bagi hasil $\left(\mathrm{X}_{2}\right)$ memiliki nilai t 2,998 > 2,004 dan signifikasi 0,004<0,05, maka Ho ditolak dan Ha diterima, yang berarti secara parsial variabel bagi hasil berpengaruh signifikan terhadap jumlah tabungan mudharabab di BRI Syariah Cabang Jember. Selain itu $t_{\text {hitung }}$ yang diperoleh adalah positif, oleh karena itu, apabila ada peningkatan pada variabel bagi hasil maka akan meningkatkan jumlah tabungan mudharabab;

3. Variabel kesesuaian hukum syariah $\left(\mathrm{X}_{3}\right)$ memiliki nilai t 2,972 $>$ 2,004 dan signifikasi 0,004 < 0,05, maka Ho ditolak dan Ha diterima, yang berarti secara parsial variabel kesesuaian hukum syariah berpengaruh signifikan terhadap jumlah tabungan mudharabah di BRI Syariah Cabang Jember. Selain itu $t_{\text {hitung }}$ yang diperoleh adalah positif, oleh karena itu, apabila ada peningkatan pada variabel kesesuaian hukum syariah maka akan meningkatkan jumlah tabungan mudharabab;

4. Variabel reputasi bank $\left(\mathrm{X}_{4}\right)$ memiliki nilai t 3,694 > 2,004 dan signifikan 0,001 < 0,05, maka Ho ditolak dan Ha diterima, yang berarti secara parsial variabel reputasi bank berpengaruh signifikan terhadap jumlah tabungan mudharabah di BRI Syariah Cabang Jember. Selain itu $t_{\text {hitung }}$ yang diperoleh adalah positif, oleh karena itu, apabila ada peningkatan pada variabel reputasi bank maka akan meningkatkan jumlah tabungan mudharabab;

5. Variabel informasi yang diperoleh nasabah $\left(\mathrm{X}_{5}\right)$ memiliki nilai $\mathrm{t}$ 2,826 > 2,004 dan signifikan 0,007 < 0,05, maka Ho ditolak dan 
Ha diterima, yang berarti secara parsial variabel informasi yang diperoleh nasabah berpengaruh signifikan terhadap jumlah tabungan mudharabah di BRI Syariah Cabang Jember. Selain itu $\mathrm{t}_{\text {hitung }}$ yang diperoleh adalah positif, oleh karena itu, apabila ada peningkatan pada variabel informasi yang diperoleh nasabah maka akan meningkatkan jumlah tabungan mudharabah.

Guna mengetahui besarnya proporsi atau sumbangan pengaruh variabel independen terhadap variabel dependen secara keseluruhan maka dapat ditentukan dengan uji koefisien determinasi berganda $\left(\mathrm{R}^{2}\right)$. Dilihat dari nilai koefisien determinasi berganda, hasil analisis menujukkan bahwa besarnya persentase sumbangan pengaruh variabel tingkat kepercayaan, bagi hasil, kesesuaian hukum syariah, reputasi bank dan informasi yang diperoleh nasabah terhadap jumlah tabungan mudharabah di BRI Syariah Cabang Jember, dapat dilihat dari nilai Adjusted $R$ Square $\left(\mathrm{R}^{2}\right)$ menunjukkan sebesar 0,807 atau $80,7 \%$ dan sisanya 19,3\% dipengaruhi atau dijelaskan oleh faktor-faktor lain yang tidak dimasukkan dalam model penelitian ini, seperti kemampuan dan pengetahuan nasabah, dan pelayanan yang diberikan oleh penyedia jasa perbankkan.

\section{Hasil Penelitian}

Pengarub Tingkat Kepercayaan Terhadap Jumlah Tabungan Mudharabah di BRI Syariah Cabang Jember

Hasil penelitian yang dilakukan, menunjukkan bahwa nilai koefisien variabel tingkat kepercayaan sebesar 0,284 atau 28,4\% dengan arah positif. Penelitian ini menemukan bahwasannya tingkat kepercayaan nasabah berpengaruh signifikan terhadap jumlah tabungan mudhrabah di BRI Syariah Cabang Jember Hal ini berarti bahwa setiap adanya kenaikan tingkat kepercayaan maka akan mempengaruhi peningkatan jumlah tabungan mudharabah nasabah. Apabila terdapat penurunan tingkat kepercayaan maka akan mempengaruhi penurunan jumlah tabungan mudharabah nasabah. Hasil penelitian ini sejalan dengan penelitian yang dilakukan oleh Hermanto (2006) yang menyatakan bahwa kepercayaan berpengaruh positif terhadap loyalitas pelanggan. 
Dengan adanya kepercayaan konsumen terhadap penyedia jasa akan meningkatkan nilai hubungan yang terjalin dengan penyedia jasa. Selain itu penelitian yang dilakukan oleh Desiana (2011) menyatakan bahwa peningkatan simpanan Mudharabah menunjukkan tingkat kepercayaan nasabah kepada BRI Syariah juga meningkat. Penelitian dengan hasil yang sama dilakukan oleh Maski (2010) menyatakan bahwa keseluruhan responden setuju bahwa bank syariah mampu memberikan kepercayaan dan memberikan pelayanan sehingga nasabah tidak memiliki keraguan untuk menambah tabungannya.

\section{Pengarub Bagi Hasil Terhadap Jumlah Tabungan Mudharabah di BRI Syariah Cabang Jember}

Penelitian yang dilakukan menunjukkan bahwa nilai koefisien variabel bagi hasil sebesar 0,245 atau 24,5\% dengan arah positif. Penelitian ini menemukan bahwasannya bagi hasil yang ditawarkan oleh pihak bank syariah akan berpengaruh signifikan terhadap jumlah tabungan mudhrabah di BRI Syariah Cabang Jember.Hal ini berarti bahwa setiap adanya kenaikan bagi hasil maka akan mempengaruhi peningkatan jumlah tabungan mudharabah nasabah. Apabila terdapat penurunan bagi hasil maka akan mempengaruhi penurunan jumlah tabungan mudharabah nasabah. Hasil penelitian ini sejalan dengan penelitian yang dilakukan oleh Okumus (2005) yang menyatakan bahwa motivasi sekunder pemanfaatan bank Islam adalah dilandasi oleh prinsip bebas bunga yang diterapkan dengan model nisbah bagi hasil. Penelitian dengan hasil yang sama selanjutnya menyatakan bahwa hasil kedua dari penelitian tersebut adalah tingkat bagi hasil berpengaruh positif dan signifikan terhadap perilaku menabung di bank syariah bagi semua kelompok nasabah yakni penelitian yakni penelitian dari Muhlis (2011). Penelitian yang dilakukan oleh Maski (2010) menyatak bahwa Sebagian nasabah memperhatikan bagi hasil dalam perilaku penambahan tingkat menabung sehingga terhindar dari riba. 
Pengarub Kesesuaian Hukum Syariah Terhadap Jumlab Tabungan Mudharabah di BRI Syariah Cabang Jember

Penelitian yang dilakukan menunjukkan bahwa nilai koefisien variabel kesesuaian hukum syariah sebesar 0,225 atau 22,5\% dengan arah positif. Penelitian ini menemukan bahwasannya kesesuaian hukum syariah berpengaruh signifikan terhadap jumlah tabungan mudhrabah di BRI Syariah Cabang Jember Hal ini berarti bahwa setiap adanya peningkatan kegiatan yang sesuai dengan hukum syariah maka akan mempengaruhi kenaikan jumlah tabungan mudharabah nasabah. Apabila terdapat penurunan kegiatan yang sesuai dengan hukum syariah maka akan mempengaruhi penurunan jumlah tabungan mudharabah nasabah. Hasil penelitian ini sejalan dengan beberapa penelitian terdahulu. Penelitian okomus (2005) menjelaskan bahwa kriteria utama seleksi oleh konsumen dalam penambahan tabungan adalah berbasis agama. Penelitian laila (2007) menjelaskan bahwa religiusitas dan pendapatan karyawan berpengaruh terhadap jumlah tabungannya karyawan tetap di BMT Ben Taqwa Grobogan. Penelitian yang dilakukan oleh Setiawan dan Ananada (2014) menghasilkan bahwa secara simultan dan parisal persepsi religiusitas dan kepuasan nasabah berpengaruh signifikan terhadap loyalitas nasabah. Ketika persepsi religiusitas yang diterima oleh nasabah BRI Syariah meningkat maka hal tersebut akan menaikan loyalitas nasabah untuk meningkatkan tabungan di BRI Syariah, karena umat Islam adalah umat yang sangat menjunjung tinggi nilainilai ajaran Islam, ketika BRI Syariah dapat menerapkan ajaran Islam dengan baik dan benar, maka akan dapat mendorong nasabah BRI Syariah lebih loyal dalam menambah jumlah tabunganya. Penelitian Muhlis (2011) menyatakan bahwa religiusitas berpengaruh positif terhadap perilaku menabung. Kelompok masyarakat muslim cenderung meningkatkan tabungannya dan menetapkan dirinya cenderung sebagai nasabah karena alasan emosional-ideologis. Maski (2010) menyatakan bahwa nasabah memperhatikan prinsip syariah dalam menambah jumlah tabungannya. Dan penelitian Machmudah (2009) menyatakan bahwa variabel religius stimuli (X3) 0.079 memberikan kontribusi terhadap meningkatnya minat nasabah non-muslim menjadi nasabah bank CIMB Niaga Syariah Cabang Semarang. 
Pengaruh Reputasi Bank Terhadap Jumlab Tabungan Mudharabah di BRI Syariah Cabang Jember

Hasil penelitian yang dilakukan menunjukkan bahwa nilai koefisien variabel reputasi bank sebesar 0,265 atau 26,5\% dengan arah positif. Penelitian ini menemukan bahwasannya reputasi bank berpengaruh signifikan terhadap jumlah tabungan mudhrabah di BRI Syariah Cabang Jember. Hal ini berarti bahwa setiap adanya peningkatan reputsi bank maka akan mempengaruhi kenaikan jumlah tabungan mudharabah nasabah. Apabila terdapat penurunan reputasi bank maka akan mempengaruhi penurunan jumlah tabungan mudharabah nasabah.

Hasil penelitian ini sejalan dengan penelitian yang dilakukan oleh Sunarto 2006 yang menyatakan bahwa variabel reputasi merek, kepuasan nasabah, dan kualitas pelayanan menjadi penentu tingkat loyalitas pelanggan BRITAMA BRI cabang Kendal. Dengan terpenuhinya ketiga faktor tersebut maka nasabah bank akan semakin loyal untuk menjalin hubungan dengan pihak bank terutama dengan meningkatkan tabungan mereka. Penelitian yang dilakukan oleh Muhlis tahun 2011 menyatakan bahwa dan hasil ketiga tingkat kepercayaan atas soliditas dan reputasi bank syariah berpengaruh positif, dan signifikan bagi peningkatan tabungan nasabah. penelitian Machmudah tahun 2009 menyatakan bahwa Variabel reputasi (X4) mempunyai pengaruh terhadap minat nasabah non muslim menjadi nasabah di Bank CIMB Niaga Syariah Cabang Semarang sebesar 0,12.

Pengaruh Informasi yang diperoleh nasabah Terhadap Jumlah Tabungan

Hasil penelitian ini menunjukkan bahwa nilai koefisien variabel informasi yang diperoleh nasabah sebesar 0,178 atau 17,8\% dengan arah positif. Penelitian ini menemukan bahwasannya informasi yang diperoleh nasabah nasabah berpengaruh signifikan terhadap jumlah tabungan mudhrabah di BRI Syariah Cabang Jember Hal ini berarti bahwa setiap adanya peningkatan informasi yang diperoleh nasabah kepada nasabah maka akan mempengaruhi 
kenaikan jumlah tabungan mudharabah nasabah. Apabila terdapat penurunan informasi yang diperoleh nasabah kepada nasabah maka akan mempengaruhi penurunan jumlah tabungan mudharabah nasabah.. Hasil penelitian ini sejalan dengan penelitian ynag dilakukan oleh Daulay tahun 2011 yang menyatakan bahwa keputusan menambah jumlah tabungan nasabah Bank Syariah Mandiri dipengaruhi adanya pengetahuan atau informasi tentang bagi hasil. Penambahan jumlah tabungan juga dipengaruhi oleh pelayanan dan informasi yang diperoleh nasabah yang dibutuhkan oleh nasabah, baik informasi positif mapun informasi negatif. Selain itu penelitian yang dilakukan oleh Desiana menyatakan bahwa simpanan Mudharabah dari tahun 2008-2010 mengalami peningkatan, karena pihak nasabah memperoleh informasi bahwa bank dalam kondisi yang baik atau sehat. Peningkatan simpanan Mudharabah menunjukkan tingkat kepercayaan nasabah kepada BRI Syariah juga meningkat.

\section{Kesimpulan}

Berdasarkan hasil analisis yang telah dilakukan pada penelitian ini, maka dapat ditarik kesimpulan bahwa: 1) Tingkat kepercayaan berpengaruh signifikan terhadap jumlah tabungan mudharabah di BRI Syariah Cabang Jember dengan arah positif; 2) Bagi hasil berpengaruh signifikan terhadap jumlah tabungan mudharabah di BRI Syariah Cabang Jember dengan arah positif; 3) Kesesuaian hukum syariah berpengaruh signifikan terhadap jumlah tabungan mudharabah di BRI Syariah Cabang Jember dengan arah positif; 4) Reputasi bank berpengaruh signifikan terhadap jumlah tabungan mudharabah di BRI Syariah Cabang Jember dengan arah positif; 5) Informasi y berng diperoleh nasabah pengaruh signifikan terhadap jumlah tabungan mudharabah di BRI Syariah Cabang Jember dengan arah positif. 


\section{Daftar Pustaka}

Antonio, Muhammad Syafi'i. 2011. Bank Syariah: dari Teori ke Praktik. CetXVII. Gema Insani. Jakarta.

Antonio, Muhammad Syafei. 2005. Bank Syariab Suatu Pengenalan Umum.Tazkia Institute. Jakarta.

Daulay, Raihanah. 2011. Pengaruh Kualitas Pelayanan dan Bagi Hasil terhadapKeputusan Menabung Nasabah pada Bank Mandiri Syariah di Kota Medan. Jurnal Skripsi.

Desiana, Mohamad Heykal. 2011. Analisis Kinerja Keuangan Bank Syariah (Studi Kasus PT BRI Syariah Indonesia, Tbk). E_ Jurnal Skripsi.

Dharmmesta, B.S., dan Irawan. 2005. Manajemen Pemasaran Modern. Liberty.Yogyakarta.

Fitrijanti, Tettet dan Jogiyanto Hartono M. 2005. Kesempatan Investasi:Konstruksi Proksi dan Analisis Hubungannya dengan KebijakanPendanaan dan Dividen. Jurnal Riset Akuntansi Indonesia 5 (1): 35-63.

Hermanto, Ken Agung. 2006. Analisis Pengaruh Kualitas Layanan, Komitmen, dan Kepercayaan terhadap Loyalitas Konsumen (Studi Kasus Pada Nasabah Tabungan SIMPEDA Bank JATENG). Tesis. Universitas Diponegoro. Semarang.

Kusrini, Andri Koniyo. 2007. Tuntunan Praktis Membangun Sistem Informasi Akuntansi Dengan Visual Basic dan Microsoft SQL Server. Andi. Yogyakarta.

Laila, Ari Alfiatul. 2007. Pengaruh Religiusitas dan Pendapatan Terhadap Jumlah Tabungan Karyawan Pada BMT Ben Taqwa Grobogan. Skripsi. STAIN Kudus.

Machmudah, Rifa'atul. 2009. Faktor-Faktor yang Mempengaruhi Minat Nasabah Non Muslim Menjadi Nasabah di Bank 
Syariah (Studi Pada Bank CIMB Niaga Syariah Cabang Semarang). Skripsi. IAIN Walisongo Semarang.

Maski, Ghozali 2010. Analisis Keputusan Nasabah Menabung Pendekatan Komponen dan Model Logitik Studi pada Bank Syariah di Bank Malang. Journal of Indonesian Applied Economics 4(1): 43-57

Muchlis, Mustakim. 2013. Faktor-Faktor yang Mempengaruhi Nasabah dalam Memilih Bank (Bank Syariah Vs Bank Konvensional). Jurnal Assets. 3(1):60-77

Mustaqim, Yunus. 2006. Motivasi Nasabah Non-Muslim Berafiliasi di LembagaKeuangan Syari'ah (Studi Kasus di BMT Bina Ummat Sejahtera Lasem). Skripsi. STAIN Kudus.

Okumus, H. 2005. Interest-Free Banking in Turkey: A Study of CustomerSatisfactin and Bank Selection Criteria. Journal of EconomicCooperation 26(4): 51-86.

Rahmawaty, Anita. 2008. Analisis Pemicu Perbedaan Motivasi Nasabah Berafiliasi Antara Bank Konvensional Dan Bank Syariah Di Semarang. Kumpulan makalah ACIS. Penguatan Peran Perguruan Tinggi Agama Islam Dalam Meningkatkan Daya Saing Bangsa. E_Jurnal Skripsi.

Roziq, Ahmad dan Rinanda Fitri D. 2013. Variabel Penentu dalam KeputusanMemilih Tabungan Mudharabah Pada Bank Syariah Mandiri Cabang Jember. Jurnal Ekonomi Akuntansi dan Manajemen. 12(1): 47-65

Setiwan, Faisal Indra \& Ananda Sabil Hussein. 2014. Pengaruh Persepsi Religiusitas terhadap Loyalitas Nasabah BRI Syariah Kota Cirebon dengan kepuasan Nasabah sebagai Variabel Intervening. E_Jurnal Skripsi 
Sunarto. 2006. Analisis Faktor-Faktor Yang Mempengaruhi Loyalitas Pelanggan Dan Dampaknya terhadap Keunggulan Bersaing (Studi pada Tabungan Britamma BRI Kenca Kendal). Tesis. Magister Manajemen Universitas Diponegoro Semarang.

Wirdyaningsih. 2005. Bank dan asuransi Islam di Indonesia. Prenada Media. Jakarta. 